\title{
Effects of the Endogenous Scope of Preferentialism on International Goods Trade
}

\section{Journal Article}

\section{Author(s):}

Egger, Peter; Wamser, Georg

Publication date:

2013-07

Permanent link:

https://doi.org/10.3929/ethz-b-000077662

\section{Rights / license:}

In Copyright - Non-Commercial Use Permitted

Originally published in:

The B.E. journal of economic analysis \& policy 13(2), https://doi.org/10.1515/bejeap-2012-0067 


\title{
Contributions
}

\section{Peter Egger* and Georg Wamser Effects of the Endogenous Scope of Preferentialism on International Goods Trade}

\begin{abstract}
Previous empirical research has assumed that goods trade responds to goods trade preferentialism only, while other forms of preferentialism - such as services trade or investment preferentialism - are irrelevant for goods trade. This article provides novel evidence for the gains from a broader scope of preferentialism (in terms of the number of dimensions covered: goods, services, and investment) at the intensive and extensive country margins of bilateral goods trade.
\end{abstract}

Keywords: preferentialism, international trade, multiple treatments, endogenous treatments, ordered probit

JEL Codes: F14, F15, C21, C22

*Corresponding author: Peter Egger, ETH Zürich, KOF, Weinbergstrasse 35, WEH E6, 8092 Zürich, Switzerland, E-mail: egger@kof.ethz.ch

Georg Wamser, University of Tübingen, Melanchthon-str. 30, 72074 Tübingen, Germany, E-mail: wamser@kof.ethz.ch

\section{Introduction}

Preferential market access is known to stimulate goods trade among insider countries relative to outsider countries on average (see Baier and Bergstrand 2007, 2009). Previous empirical research on the direct effect of preferentialism on countries' trade relied on the paradigm that, in the policy domain, only preferential goods market access matters for goods trade. But preferentialism extends beyond the boundaries of goods trade: many recent trade agreements contain provisions for goods trade, services trade, and investment (see Horn, Mavroidis, and Sapir 2010; Baldwin 2011); services and goods trade are complementary and often even hard to disentangle (see Baldwin 2011); and foreign investment activities of multinational firms are complementary to goods trade (see Helpman, Melitz, and Yeaple 2004; Ekholm, Forslid, and Markusen 2007), 
so that provisions about services or investment matter for goods trade (see Egger and Wamser 2013). ${ }^{1}$ Hence, preferential market access for each goods, services, and investments should matter for goods trade. Preferential market access provisions are traditionally implemented by way of four types of preferential agreements: goods trade agreements (GTAs), services trade agreements (STAs), bilateral or multilateral investment agreements (BITs), and double taxation agreements (DTTs) (see Egger and Wamser 2013). Empirically, there is overlap in those provisions for two reasons: some country-pairs sign independent agreements in the different dimensions with each other, and others implement deep integration agreements (mostly associated with customs unions) which provide provisions in several domains (goods, services, cross-border investment, etc.).

From a theoretical point of view, we would expect non-goods-trade provisions to affect goods trade positively if, on net, other affected outcomes are complementary to goods trade (e.g. through the complementarity of services trade and goods trade or the complementarity of foreign direct investment and goods trade). Examples are transport services and goods trade, financial services and goods trade, or the activity of vertical multinational firms and goods trade. Such complementarities may surface across firms (through interdependencies established by the market) or within firms. One would expect, on the other hand, a substitutive relationship between non-goods-trade provisions and goods trade, if service trade activities or foreign direct investment would compete with goods trade for similar resources (e.g. production factors or consumer expenditures).

Rather than focusing on the impact of one dimension of preferentialism (namely, GTAs) on bilateral goods trade, this article assesses the (causal) impact of the scope of preferentialism on goods trade - measured by the considered (most important) four dimensions in which preferential market access can be granted between a pair of countries. We utilize panel data on all GTAs, STAs, BITs, and DTTs among 210 countries between 1960 and 2005 (covering 2,018,940

\footnotetext{
1 In general, there is heterogeneity about any type of agreements regarding the extent of market access and the so-called preference margins granted across different activities (goods with goods trade, services with services trade, and investment-related activities with foreign direct investment). We account for such heterogeneity to the extent that we distinguish between agreements that contain goods trade provisions only, ones that capture goods and services trade provisions, ones that capture goods and investment provisions, and ones that capture goods, services, and investment provisions. However, even GTAs with goods provisions only differ with regard to the tariff lines (products) covered and the preference margins granted (i.e. the difference between the applied tariff outside the agreement and the one charged within the agreement). Accounting for the latter type of heterogeneity lies beyond the scope of this article (see Baier and Bergstrand, 2004, 2007, and 2009, for a similar approach in that regard).
} 
observations and 43,890 country-pairs). ${ }^{2}$ Based on those data, we define an ordered index, ranging from 0 to 4 , reflecting the number of dimensions in which preferential market access is granted in a pair of countries. Notice that any value from 1 to 3 is not unique in terms of the specific types of agreements it is based upon. No matter of whether a GTA, an STA, a BIA, or a DTT is concluded in isolation, the scope of preferentialism is always 1 and refers to the average effect of any single type of agreement, and similarly for a scope of 2 or 3. We then estimate the probabilities of granting preferential market access in the 0-4 dimensions as a function of economic, geographical, and political fundamentals for every country-pair and year. Finally, we utilize the estimated probabilities in a selection-on-observables framework to estimate the causal effect of a broader versus a narrower scope of preferentialism on bilateral goods trade for the average treated country-pair and year.

It is worth noting that preferentialism of any kind - not only in the goods trade domain - evolved particularly dynamically since the early 1990s. Hence, a panel data-set of country-pairs which starts as early as 1960 contains numerous zeros (no type of preferentialism is granted at all), in particular, in the earlier (especially the first three) covered decades. Accordingly, not any form of preferential market access is granted in $86 \%$ of the observations covered, which implies that the probability of drawing a zero-ordered index across all years and countrypairs is $86 \%$. About $11 \%$ of the observations have one type of agreement (grant a scope of 1), about $2.5 \%$ grant a scope of 2 , only $0.59 \%$ and less than $0.001 \%$ grant preferentialism in three and four dimensions. As said before, there is a tendency toward a broader scope of preferentialism for the average country-pair as time marches on: in 10,463 year-to-year comparisons, country-pairs increased the scope of preferentialism, while in only 324 year-to-year comparisons, countrypairs reduced the scope of preferentialism (the rest are non-changers since 1960).

Tables 1 and 2 present numbers for the intensive and extensive country margins of goods exports between country-pairs for different scopes of preferentialism in the whole panel (Table 1) and for the most recent year covered, namely 2005 (Table 2). On average, positive trade tends to be more likely and bigger between country-pairs with more preferentialism than between ones with less preferentialism. The lower panels of Tables 1 and 2 suggest that bilateral exports were non-zero for about $61 \%$ and about $78 \%$ of the observations in the

2 Many GTAs include services trade and investment provisions. For instance, this is obvious from a new data-set compiled by the World Trade Organization. In accordance with that dataset, we classify country-pairs to have services trade provisions whenever they appear in a GTA or a separate STA. Similarly, we classify country-pairs to have investment provisions no matter whether they appear in a trade agreement or a bilateral investment agreement. 
Table 1: Intensive and extensive country margin of goods exports over all years (1960-2005).

\begin{tabular}{llrrrr}
\hline $\begin{array}{l}\text { Scope of preferential } \\
\text { agreements }\end{array}$ & Mean & Std. Dev. & Min. & Max. & Obs. \\
\hline Intensive margin & & & & & \\
0 & 0.316 & 2.972 & -6.908 & 11.896 & 269,147 \\
1 & 2.474 & 3.163 & -6.908 & 12.236 & 51,062 \\
2 & 4.205 & 2.555 & -6.908 & 11.997 & 13,202 \\
3 & 5.768 & 2.076 & -1.822 & 12.602 & 3,247 \\
4 & 6.308 & 1.599 & 1.785 & 9.846 & 492 \\
All & 0.857 & 3.195 & -6.908 & 12.602 & 337,150 \\
Extensive margin & & & & & \\
0 & 0.568 & 0.495 & 0 & 1 & 473,489 \\
1 & 0.867 & 0.340 & 0 & 1 & 58,911 \\
2 & 0.968 & 0.176 & 0 & 1 & 13,637 \\
3 & 0.998 & 0.043 & 0 & 1 & 3,253 \\
4 & 1.000 & 0.000 & 1 & 1 & 492 \\
All & 0.613 & 0.487 & 0 & 1 & 549,782 \\
\hline
\end{tabular}

Notes: The Scope of Preferential Agreements is a count of the number of preferential integration agreement dimensions covered between country-pairs. Preferential market access is measured in four dimensions: GTAs; STAs; Double Taxation Treaties (DTTs); and Bilateral Investment Treaties (BITs). Data on bilateral goods trade are taken from the United Nations' Comtrade Database. The intensive bilateral (country) margin is the $\log$ of the bilateral goods exports between country-pairs. The extensive bilateral (country) margin measures the propensity to observe positive goods trade. Numbers are calculated using all available country-pairs and years.

whole panel and in 2005, respectively. Moreover, these panels show that bilateral exports were non-zero for about $57 \%$ and $71 \%$ of the observations in the whole panel and in 2005, respectively, with no preferentialism granted whatsoever. Finally, these panels show that bilateral exports were non-zero for more than $87 \%$ and $93 \%$ of the observations in the whole panel and in 2005, respectively, with some preferentialism granted (scope 1). The upper panels demonstrate that bilateral goods exports (measured in logs) increase as the scope of preferential agreements increases. At the same time, the number of observations the calculated mean values are based upon decreases in the scope.

Figures 1-3 provide evidence of the average scope of preferentialism per country. In order to be able to draw maps, we compute the average scope per country across all partners in three different years: 1965, 1985, and 2005. Notice that, while the original scope variable is an integer which takes on values between 0 and 4, the average across a country's partners in a year leads to a real number which is bounded from below by 0 and from above by 4 . That number may be higher due to broadening the set of partners with which a country entertains a low scope of preferentialism or by raising the scope with 
Table 2: Intensive and extensive country margin of goods exports in 2005.

\begin{tabular}{|c|c|c|c|c|c|}
\hline $\begin{array}{l}\text { Scope of preferential } \\
\text { agreements }\end{array}$ & Mean & Std. Dev. & Min. & Max. & Obs. \\
\hline \multicolumn{6}{|l|}{ Intensive margin } \\
\hline 0 & 0.113 & 3.234 & -6.908 & 10.226 & 8,129 \\
\hline 1 & 2.743 & 3.242 & -6.908 & 12.236 & 2,676 \\
\hline 2 & 4.559 & 2.738 & -6.908 & 11.467 & 1,136 \\
\hline 3 & 5.929 & 2.042 & 0.515 & 12.602 & 392 \\
\hline 4 & 6.628 & 1.547 & 2.324 & 9.846 & 122 \\
\hline All & 1.330 & 3.635 & -6.908 & 12.602 & 12,455 \\
\hline \multicolumn{6}{|l|}{ Extensive margin } \\
\hline 0 & 0.707 & 0.455 & 0 & 1 & 11,500 \\
\hline 1 & 0.927 & 0.261 & 0 & 1 & 2,888 \\
\hline 2 & 0.990 & 0.098 & 0 & 1 & 1,147 \\
\hline 3 & 0.997 & 0.050 & 0 & 1 & 393 \\
\hline 4 & 1.000 & 0.000 & 1 & 1 & 122 \\
\hline All & 0.776 & 0.417 & 0 & 1 & 16,050 \\
\hline
\end{tabular}

Notes: The Scope of Preferential Agreements is a count of the number of preferential integration agreement dimensions covered between country-pairs. Preferential market access is measured in four dimensions: GTAs; STAs; DTTs; and BITs. Data on bilateral goods trade are taken from the United Nations' Comtrade Database. The intensive bilateral (country) margin is the $\log$ of the bilateral goods exports between country-pairs. The extensive bilateral (country) margin measures the propensity to observe positive goods trade. Numbers are calculated using all available country-pairs for the year 2005.

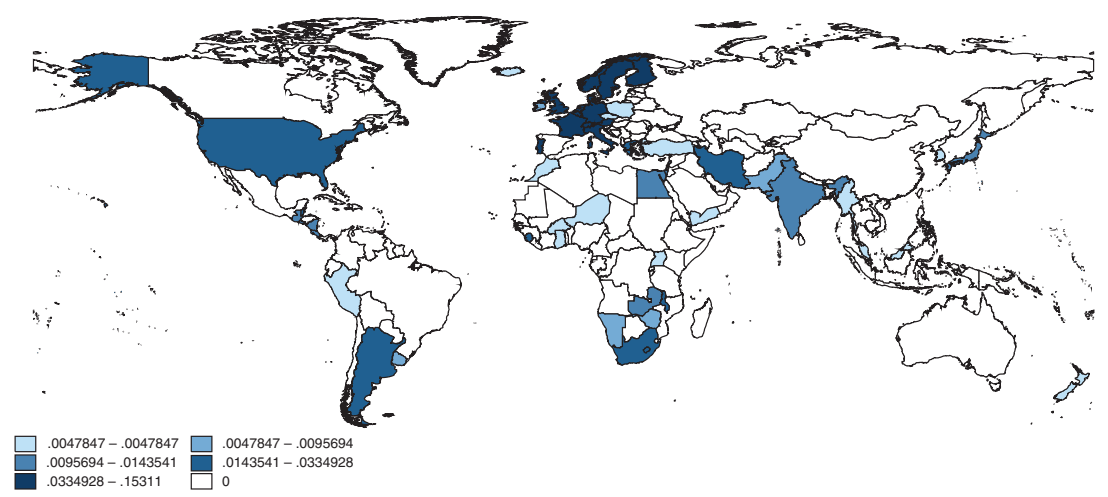

Figure 1: Avg. scope of preferentialism by country (1965).

a given number of preferential trading partners. In the figures, we use blue color allotted to five quantiles of the distribution of the average scope of preferentialism across countries, where a darker color indicates a bigger average scope and a lighter color indicates the opposite. The figures suggest that developed countries were faster in granting preferential market access - mostly vis-à-vis 


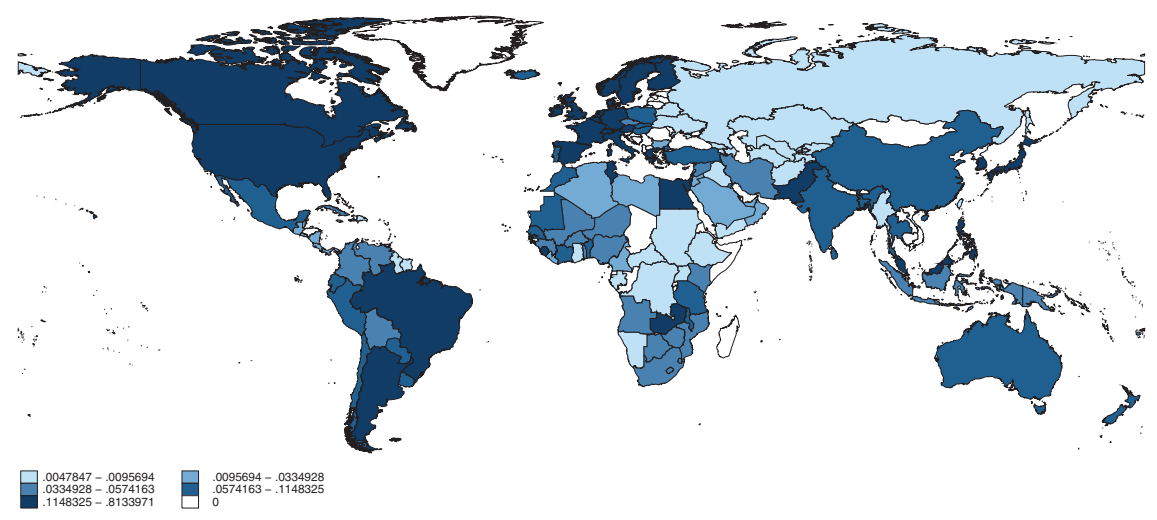

Figure 2: Avg. scope of preferentialism by country (1985).

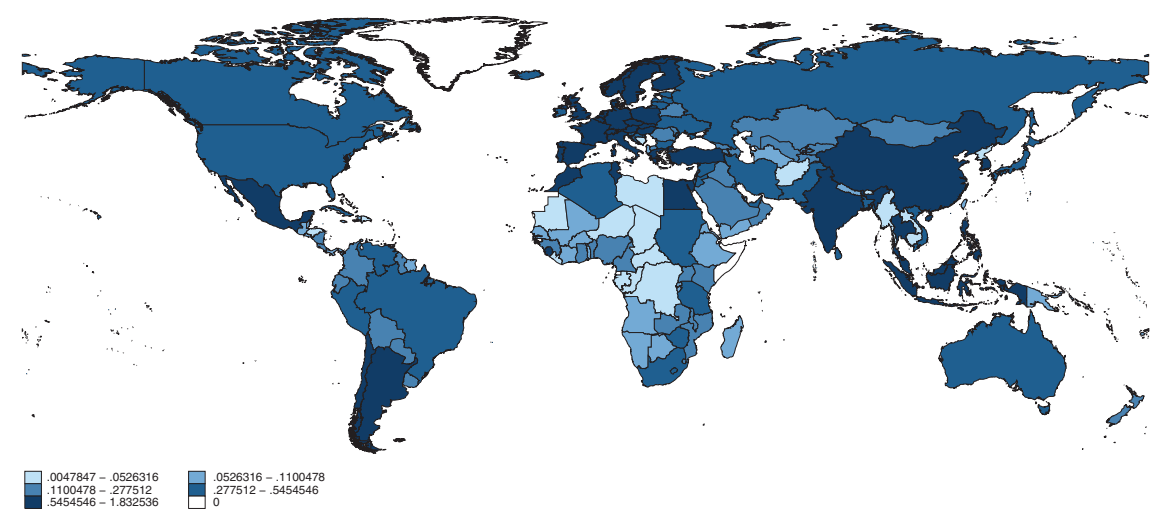

Figure 3: Avg. scope of preferentialism by country (2005).

Notes: The figures illustrate the average scope of preferentialism across a country's partners in a year, which is a real number that is bounded from below by 0 and from above by 4 . That number may be higher due to broadening the set of partners with which a country entertains a low scope of preferentialism or by raising the scope with a given number of preferential trading partners. White color refers to a scope of preferentialism of 0 and blue color to one of five quantiles of a positive average scope of preferentialism across countries.

each other - than developing countries. This is evident from the numerous countries that are colored white in the map for 1965. The later years of the data display a significant involvement of developing countries in preferentialism, mostly with developed economies but also among each other. The latter shows in the larger number of colored countries in the map for 2005 relative to the ones for 1965 and 1985. 


\section{Modeling the effects of an endogenous scope of preferentialism}

Let us suppose that the scope of preferentialism between countries $i$ and $j$ in year $t$ is determined by a latent process of the form

$$
Y_{i j t}=\mathbf{X}_{i j t} \boldsymbol{\beta}+u_{i j t},
$$

where $Y_{i j t}$ measures the (latent) net gains from preferentialism, $\mathbf{X}_{i j t}$ is a $1 \times K$ vector of observable determinants of the scope of preferentialism, $\boldsymbol{\beta}$ is a vector of parameters (including pair-specific fixed effects and time-specific effects), ${ }^{3}$ and $u_{i j t}$ is a disturbance term. We assume that $u_{i j t}$ is normally distributed and eq. [1] can be estimated by way of an ordered panel probit model (see Wooldridge 2002). $Y_{i j t}$ is assumed to generate an ordered index for the scope of preferentialism as $S_{i j t}=0$ if $Y_{i j t} \leq \mu_{1}=0 ; S_{i j t}=1$ if $0<Y_{i j t} \leq \mu_{2} ; \ldots ; S_{i j t}=4$ if $\mu_{3}<Y_{i j t}$; where $\mu_{s}$ are constants for $s \in\{1, \ldots, 3\}$.

Apart from fixed pair and time effects, $\mathbf{X}_{i j t}$ includes variables that have been found to be important for selection into the types of preferential agreements included here. These variables reflect country size (absolute and relative) factor endowments, trade and investment costs in a broad sense, and political costs. ${ }^{4}$ Table 3 defines the corresponding variables and mentions their data sources. We suppress descriptive statistics of observables here for the sake of brevity.

3 We follow the Mundlak-Chamberlain-Wooldridge device to parameterize fixed pair effects as an additive function of averaged time-variant covariates in $\mathbf{X}_{i j t}$ (see Mundlak 1978; Chamberlain 1982; Wooldridge 2002).

4 In the following, we provide a highly selective list of examples of work in economics which focused on the determinants or consequences of just one dimension of preferential market access.

Work on the causes of agreements. GTAs-theory: Baldwin (1995, 1997); Bond and Syropoulos (1996); Limao and Tovar Rodriguez (2011); Arcand, Olarreaga, and Zoratto (2010); GTAsempirics: Magee (2003); Baier and Bergstrand (2004); Bergstrand, Egger, and Larch (2010); STAs-theory: Huang, Whalley, and Zhang (2009); STAs-empirics: Egger and Lanz (2008); Francois and Hoekman (2010); Egger and Wamser (2013); BITs-theory: Egger, Larch, and Pfaffermayr (2007a, b); BITs-empirics: Bergstrand and Egger (2011); DTTs-theory: Davies (2003, 2004); DTTs-empirics: Egger, Larch, Pfaffermayr, and Winner (2006).

Work on the consequences of agreements. GTAs-theory: Frankel, Stein, and Wei (1995); Freund (2000); Ornelas (2005a-c); Limao (2007); Karacaovali and Limao (2008); GTAs-empirics: Baier and Bergstrand (2007, 2009); Egger et al. (2011); STAs-theory: Huang, Whalley, and Zhang (2009); STAs-empirics: Egger, Larch, and Staub (2012); BITs-theory: Egger, Larch, and Pfaffermayr (2004, 2007a,b); BITs-empirics: Egger and Merlo (2012); Sauvant and Sachs (2009); DTTs-theory: Davies, Egger, and Egger (2010); DTTs-empirics: Blonigen and Davies (2004); Egger et al. (2006); Davies, Norbäck, and Tekin-Koru (2009). 
Table 3: Determinants of preferentialism (description and data sources).

SumGDP $_{i j t}$
SimGDP $_{i j t}$
SumPOP Pijt $_{i j}$
SimPOP
DKL
ijt

$D$ RowKL $L_{i j t}$

$\log _{\text {Distance }}{ }_{i j}$

Common Border $i j$

Common

Language $_{i j}$

Same Continent ${ }_{i j}$

WTO Member ijt $_{\text {. }}$

(one)

WTO Member ijt $_{\text {. }}$

(both)

Landlocked $_{i j}$ (one)

Landlocked $_{i j}$ (both)

CDWar $_{i j t}$

DiffYearWar $_{i j t}$

DiffRegDur ${ }_{i j t}$

DiffPolFreed $_{i j t}$
Defined as $\ln G D P_{i j t}$ with $G D P_{i j t} \equiv\left(G D P_{i t}+G D P_{j t}\right)$, where $G D P_{i t}$ is a country's real GDP in U.S. dollars of the year 2000 (Source: World Bank's World Development Indicators, WDI).

Defined as $\ln \left[1-\left(G D P_{i t} / G D P_{i j t}\right)^{2}-\left(G D P_{j t} / G D P_{i j t}\right)^{2}\right]$ (Source: WDI).

Defined analogous to $S u m G D P_{i j t}$, except for using population numbers $P O P_{i t}$ and $P O P_{j t}$ instead of $G D P_{i t}$ and $G D P_{j t}$, respectively (Source: WDI). Constructed akin to $\operatorname{Sim} G D P_{i j t}$ (Source: WDI).

Capturing the difference in two countries' relative factor endowments, measured as $\left|\ln \left(G D P_{i t} / P O P_{i t}\right)-\ln \left(G D P_{j t} / P O P_{j t}\right)\right|$ (Source: WDI).

The squared value of $D K L_{i j t}$ (Source: WDI).

The average distance of two countries $i$ and $j$ from all other countries in the sample in a given year $t$. Defined as $0.5\left\{\left[\ln \Sigma_{i \neq j} D_{i j} /\left(N_{t}-1\right)\right]+\right.$ $\left.\left.\ln \Sigma_{j \neq i} D_{i j} /\left(N_{t}-1\right) \mid\right\}\right]$ (see Baier and Bergstrand, 2004), where $N_{t}$ is the number of countries in the sample as of year $t$.

The average difference in relative factor endowments (real per-capita incomes) of pair $i j$ together with all other countries in the sample in a given year $t$ (see Egger and Larch, 2008).

The log of the great circle distance ( $\ln D_{i j}$ ) between two countries' economic centers (Source: Centre dÉtudes Prospectives et d'Informations Internationales, CEPII).

An indicator variable for a common land border of $i$ and $j$ (Source: CEPII). An indicator variable for a common language of $i$ and $j$ (Source: CEPII).

An indicator variable for $i$ and $j$ being located on the same continent (Source: CEPII).

Unity whenever only one country in a pair is a member of the GATT or the WTO in year $t$ and zero else (Source: Egger and Nelson, 2010).

Unity whenever both countries in a pair are members of the GATT or the WTO in year $t$ and zero else (Source: Egger and Nelson, 2010).

An indicator variable for $i$ or $j$ to have maritime access (Source: CEPII).

An indicator variable for $i$ and $j$ to have maritime access (Source: CEPII).

Counts the number of days $i$ and $j$ had armed conflict with each other since after World War II (Source: International Institute for Strategic Studies' Armed Conflict Database).

Counts of the number of years since $i$ and $j$ had the last war with each other. If two countries never had a war, the variable is set to a maximum value of 2005 (Source: International Institute for Strategic Studies' Armed Conflict Database).

A count of the absolute difference in the number of years two countries' political regimes are in office (Source: Marshall and Jaggers' Polity IV database).

Measures the absolute difference in the Polity 2 index, which is larger if a country's political freedom is greater (Source: Marshall and Jaggers' Polity IV database). 
Table 4 summarizes the parameter estimates from four variants of an ordered panel probit model involving a latent process as in eq. [1]. Broadly, the results suggest that the scope of preferentialism between country-pairs increases in countries' size (economic and cultural) similarity, and geographical closeness. All specifications employ fixed country-pair effects by way of including means of the time-variant variables, following the Mundlak-ChamberlainWooldridge device as well as fixed year effects by way of including binary indicator variables. ${ }^{5}$

Table 4: Determinants of preferentialism (estimation results).

\begin{tabular}{|c|c|c|c|c|}
\hline Observable variables & $\begin{array}{l}\text { Base } \\
\text { specification }\end{array}$ & $\begin{array}{l}\text { Alternative BITs } \\
\text { specification }\end{array}$ & $\begin{array}{l}\text { Dynamic } \\
\text { specification }\end{array}$ & $\begin{array}{l}\text { Additional } \\
\text { spillover } \\
\text { control }\end{array}$ \\
\hline SumGDP $i j t$ & $\begin{array}{l}0.626^{\star \star \star} \\
(0.015)\end{array}$ & $\begin{array}{l}0.603^{\star \star \star} \\
(0.014)\end{array}$ & $\begin{array}{c}0.001 \\
(0.026)\end{array}$ & $\begin{array}{l}0.132^{\star \star \star} \\
(0.024)\end{array}$ \\
\hline $\operatorname{SimGDP}_{i j t}$ & $\begin{array}{l}0.302^{\star \star \star} \\
(0.011)\end{array}$ & $\begin{array}{l}0.321^{\star \star \star} \\
(0.011)\end{array}$ & $\begin{array}{c}0.010 \\
(0.019)\end{array}$ & $\begin{array}{l}0.056^{\star * \star} \\
(0.017)\end{array}$ \\
\hline SumPOP $_{i j t}$ & $\begin{array}{l}0.195^{\star \star *} \\
(0.016)\end{array}$ & $\begin{array}{l}0.243^{\star \star \star} \\
(0.016)\end{array}$ & $\begin{array}{c}-0.012 \\
(0.030)\end{array}$ & $\begin{array}{c}-0.023 \\
(0.027)\end{array}$ \\
\hline $\operatorname{SimPOP}_{i j t}$ & $\begin{array}{l}-0.795^{\star \star \star} \\
(0.019)\end{array}$ & $\begin{array}{l}-0.778^{\star \star \star} \\
(0.019)\end{array}$ & $\begin{array}{l}-0.232^{\star \star \star} \\
(0.033)\end{array}$ & $\begin{array}{l}-0.338^{\star \star \star} \\
(0.031)\end{array}$ \\
\hline $\mathrm{DKL}_{i j t}$ & $\begin{array}{c}0.024 \\
(0.016)\end{array}$ & $\begin{array}{r}-0.008 \\
(0.015)\end{array}$ & $\begin{array}{l}0.059 \star \star \\
(0.026)\end{array}$ & $\begin{array}{c}0.034 \\
(0.024)\end{array}$ \\
\hline $\mathrm{DKL}_{i j t}^{2}$ & $\begin{array}{l}-0.111^{\star \star \star} \\
(0.005)\end{array}$ & $\begin{array}{l}-0.103^{\star \star \star} \\
(0.005)\end{array}$ & $\begin{array}{l}-0.065^{\star \star \star} \\
(0.008)\end{array}$ & $\begin{array}{l}-0.062^{\star \star \star} \\
(0.008)\end{array}$ \\
\hline Remote $_{i j}$ & $\begin{array}{l}-1.237^{\star \star \star} \\
(0.128)\end{array}$ & $\begin{array}{c}-0.305^{\star \star} \\
(0.128)\end{array}$ & $\begin{array}{l}-0.752^{\star \star \star} \\
(0.249)\end{array}$ & $\begin{array}{l}-1.447^{\star \star \star} \\
(0.237)\end{array}$ \\
\hline DRowKL $_{i j t}$ & $\begin{array}{c}-0.005 \\
(0.017)\end{array}$ & $\begin{array}{l}0.247^{\star \star \star} \\
(0.016)\end{array}$ & $\begin{array}{c}0.016 \\
(0.027)\end{array}$ & $\begin{array}{l}0.090^{\star \star \star \star} \\
(0.026)\end{array}$ \\
\hline $\log$ Distance $_{i j}$ & $\begin{array}{l}-0.382^{\star \star \star} \\
(0.004)\end{array}$ & $\begin{array}{l}-0.352^{\star \star *} \\
(0.004)\end{array}$ & $\begin{array}{l}-0.212^{\star * \star} \\
(0.008)\end{array}$ & $\begin{array}{c}-0.197^{\star \star \star} \\
(0.008)\end{array}$ \\
\hline
\end{tabular}

5 In principal, all time-invariant variables and their parameters in Table 4 could be thought of as being part of the vector of country-pair fixed effects. However, we report the corresponding parameters for convenience. Moreover, one could allow for continent-specific or even countryspecific year effects rather than pooled year effects. With the data at hand, this leads to an extremely flat likelihood function which is difficult to optimize for parameter values. Therefore, we resort to the more parsimonious specification. 
Table 4: (Continued)

\begin{tabular}{|c|c|c|c|c|}
\hline Observable variables & $\begin{array}{l}\text { Base } \\
\text { specification }\end{array}$ & $\begin{array}{l}\text { Alternative BITs } \\
\text { specification }\end{array}$ & $\begin{array}{l}\text { Dynamic } \\
\text { specification }\end{array}$ & $\begin{array}{l}\text { Additional } \\
\text { spillover } \\
\text { control }\end{array}$ \\
\hline Common Border ${ }_{i j}$ & $\begin{array}{l}0.159 \star \star \star \\
(0.013)\end{array}$ & $\begin{array}{l}0.189^{\star \star \star} \\
(0.013)\end{array}$ & $\begin{array}{l}-0.025 \\
(0.026)\end{array}$ & $\begin{array}{l}-0.015 \\
(0.026)\end{array}$ \\
\hline Common Language $_{i j}$ & $\begin{array}{l}0.208^{\star \star \star} \\
(0.006)\end{array}$ & $\begin{array}{l}0.211^{\star \star \star} \\
(0.007)\end{array}$ & $\begin{array}{l}0.093^{\star \star \star} \\
(0.012)\end{array}$ & $\begin{array}{l}0.116^{\star \star \star} \\
(0.012)\end{array}$ \\
\hline Same Continent $_{i j}$ & $\begin{array}{l}0.120 * \star \star \\
(0.007)\end{array}$ & $\begin{array}{l}0.190 * * * \\
(0.007)\end{array}$ & $\begin{array}{l}0.091^{\star \star \star} \\
(0.012)\end{array}$ & $\begin{array}{l}0.102^{\star \star \star} \\
(0.012)\end{array}$ \\
\hline WTO Member ${ }_{i j t}$ (one) & $\begin{array}{l}0.506^{\star \star *} \\
(0.015)\end{array}$ & $\begin{array}{l}0.535^{\star \star \star} \\
(0.015)\end{array}$ & $\begin{array}{l}0.339 \star \star \star \\
(0.025)\end{array}$ & $\begin{array}{l}0.298^{\star \star \star} \\
(0.023)\end{array}$ \\
\hline WTO Member Met $_{\text {(both) }}$ & $\begin{array}{l}0.812^{\star \star \star} \\
(0.017)\end{array}$ & $\begin{array}{l}0.854^{\star \star \star} \\
(0.017)\end{array}$ & $\begin{array}{l}0.507^{\star \star \star} \\
(0.029)\end{array}$ & $\begin{array}{l}0.462^{\star \star \star} \\
(0.027)\end{array}$ \\
\hline Landlocked $_{i j}$ (one) & $\begin{array}{l}-0.077^{\star \star \star} \\
(0.006)\end{array}$ & $\begin{array}{l}-0.101^{\star \star \star} \\
(0.006)\end{array}$ & $\begin{array}{l}-0.032^{\star \star \star} \\
(0.011)\end{array}$ & $\begin{array}{l}-0.052^{\star \star \star} \\
(0.011)\end{array}$ \\
\hline Landlocked $_{i j}$ (both) & $\begin{array}{l}-0.050^{\star \star \star} \\
(0.015)\end{array}$ & $\begin{array}{l}-0.079 * \star \star \\
(0.016)\end{array}$ & $\begin{array}{c}0.011 \\
(0.030)\end{array}$ & $\begin{array}{c}0.005 \\
(0.028)\end{array}$ \\
\hline CDWar $_{i j t}$ & $\begin{array}{l}-0.000 \star \star \star \\
(0.000)\end{array}$ & $\begin{array}{l}-0.000 * \star \star \\
(0.000)\end{array}$ & $\begin{array}{l}-0.000 \star \star \star \\
(0.000)\end{array}$ & $\begin{array}{l}-0.000^{\star \star} \\
(0.000)\end{array}$ \\
\hline DiffYearWar $_{i j t}$ & $\begin{array}{l}-0.000 \star \star \star \\
(0.000)\end{array}$ & $\begin{array}{l}-0.000 \\
(0.000)\end{array}$ & $\begin{array}{c}0.000 \\
(0.000)\end{array}$ & $\begin{array}{c}0.000 \\
(0.000)\end{array}$ \\
\hline DiffRegDur $_{i j t}$ & $\begin{array}{l}0.002^{\star \star \star} \\
(0.000)\end{array}$ & $\begin{array}{l}0.001^{\star \star \star} \\
(0.000)\end{array}$ & $\begin{array}{l}0.001^{\star \star \star} \\
(0.000)\end{array}$ & $\begin{array}{l}0.000 * \\
(0.000)\end{array}$ \\
\hline DiffPolFreed $_{i j t}$ & $\begin{array}{l}-0.011^{\star \star \star} \\
(0.000)\end{array}$ & $\begin{array}{l}-0.010 * \star \star \\
(0.000)\end{array}$ & $\begin{array}{l}-0.003^{\star \star \star} \\
(0.001)\end{array}$ & $\begin{array}{l}-0.003^{\star \star \star} \\
(0.001)\end{array}$ \\
\hline Observations & 654,272 & 654,272 & 641,210 & 641,210 \\
\hline
\end{tabular}

Notes: Ordered panel probit estimates. All specifications include pair-specific means and year effects. ${ }^{* * *}$, **, and * indicate that coefficients are significantly different from zero at $1 \%, 5 \%$, and $10 \%$, respectively. The base specification uses a BIT indicator which is set to unity not only for cases where a BIT actually exists but also in case that a trade agreement provides for investment provisions according to the World Trade Organization. In the alternative BITs specification, only existing BITs are counted. The dynamic specification includes the dependent variable with a one-year time lag along with initial conditions according to Wooldridge (2005). The parameters on the lagged dependent variables and the initial conditions are suppressed for the sake of brevity. The last specification with additional spillover controls conditions additionally on the lagged total scope of preferentialism in a year (sum over all country-pairs) minus the scope of preferentialism of the country-pair under consideration relative to the total number of observations minus one $\left(W S_{i j t-1}=1 /(N-1) \Sigma_{k l \neq i j, t-1} S_{k l, t-1}\right)$.

The first model summarized is the base specification. The second model utilizes an alternative treatment of investment provisions (or BITs). While the base model codes preferential investment provisions as to apply no matter of whether they surface in a (goods or services) trade agreement or in a BIT, the alternative 
specification focuses on actual BITs only. This reduces the integer number of the scope of preferentialism for some of the country-pairs by one unit. The third specification adds a lagged dependent variable and controls for its endogeneity by including an initial condition as suggested by Wooldridge (2005). Not surprisingly, it turns out that there is inertia in the scope of preferentialism that country-pairs grant each other, reflected in a positive parameter point estimate which is significantly different from zero (suppressed in Table 4 for the sake of brevity). Finally, the fourth specification adds the once-lagged average scope of preferentialism in other country-pairs than $i j$ as a determinant of pair $i j$ 's preferentialism in a given year. Since the last two specifications involve lagged terms, they are based on fewer observations than the first two specifications in Table 4. It turns out that the scope of preferentialism is contagious (the parameter is suppressed in Table 4 for the sake of brevity), akin to goods trade preferentialism (see Egger and Larch 2008). While there is some difference in the parameters across the specifications in Table 4, the estimated probabilities are very similar. Hence, we proceed by using the base specification for estimating average treatment effects of the treated below.

The ordered probit obtains five $n \times 1$ vectors of probabilities $\mathbf{p}_{0}, \ldots, \mathbf{p}_{4}$ for a scope of $s \in\{0, \ldots, 4\}$. In what follows, we utilize the probabilities to estimate average treatment effects on the treated (ATTs). For treatment $s$ and control group $\tilde{s} \in\{0, \ldots, 4\}$, we may write the subvector probabilities as $\mathbf{p}_{s, \tilde{s}}$ and the average treatment effects on the treated of the extensive and intensive country margins as $A T T_{s, \tilde{s}}^{\mathcal{E}}$ and $A T T_{s, \tilde{s}}^{\mathcal{I}}$, respectively. Defining an indicator variable for the extensive country margin of bilateral trade, $\mathcal{E}_{i j t}$, which is unity whenever $i$ exports to $j$ in year $t$ and zero else and $\log$ bilateral exports for the intensive country margin of bilateral trade, $\mathcal{I}_{i j t}, A T T_{s, \tilde{s}}^{\mathcal{E}}=E\left(\mathcal{E}_{i j t}^{s}-\mathcal{E}_{i j t}^{\tilde{s}} \mid S_{i j t}=s, \mathbf{p}_{s, \tilde{s}}\right)$ and $A T T_{s, \tilde{s}}^{\mathcal{I}}=E\left(\mathcal{I}_{i j t}^{s}-\mathcal{I}_{i j t}^{\tilde{s}} \mid S_{i j t}=s, \mathbf{p}_{s, \tilde{s}}\right){ }^{6}$

While outcomes $\mathcal{E}_{i j t}^{s}$ and $\mathcal{I}_{i j t}^{s}$ are observed for observation ijt in case it has treatment $s$, counterfactual outcomes $\mathcal{E}_{i j t}^{\tilde{s}}$ and $\mathcal{I}_{i j t}^{\tilde{s}}$ have to be estimated (see Rosenbaum and Rubin, 1983). ${ }^{7}$ For the estimates of $A T T_{s, \tilde{s}}^{\mathcal{E}}$ and $A T T_{s, \tilde{s}}^{\mathcal{I}}$ to be consistent, we impose three common assumptions: conditional mean

6 The results in Egger, Larch, Staub, and Winkelmann (2011) suggest that these two margins can be analyzed as two separate parts of an integrated model.

7 In general, endogenous treatment effects' problems are ones of missing data. In our context, say, a country-pair $i j$ with a scope of preferentialism of unity in period $t$ is only observed with that treatment level. Ideally, we would like to compare this country-pair to itself with another treatment level (say, one with a scope of preferentialism of four) in the same period. However, such a data point does not exist. We can only impute (or estimate) it by finding other countrypairs in the same year which are very similar (ideally, they are identical) to country-pair $i j$. 
independence holds $(\mathrm{A} 1)^{8}$; observations with state $s$ and control units with state $\tilde{s}$ have common support in $\mathbf{p}_{s, \tilde{s}}$-space $(\mathrm{A} 2)^{9}$; and the scalar-valued propensity scores in $\mathbf{p}_{s, \tilde{s}}$ are suitable measures of similarity between observations (similarity in $\mathbf{p}_{s, \tilde{s}}$ for any pair of observations means similarity in all of the elements in observables $\mathbf{X}_{s, \tilde{s}}$ for that pair of observations; A3). ${ }^{10}$ We enforce a high quality of matching in two ways. First of all, we enforce similarity between the propensity scores of the treated and matched control units by utilizing a narrow radius of $1 \%$ and caliper matching based on a common support of propensity scores for the treated and control units. Moreover, in selecting control observations with state $\tilde{s}$ for treated observations with state $s$ which are similar in all columns of $\mathbf{X}_{s, \tilde{s}}$, we make sure that Assumptions A2 and A3 hold (see Dorn and Egger, 2011). This ensures similarity of all compared units in terms of $\mathbf{X}_{s, \tilde{s}}$ as well as in the propensity scores.

\section{Results}

Before presenting treatment effects based on matching, we summarize parametric average treatment effects based on fixed effects regressions. Baier and Bergstrand (2007) - using panel data on bilateral exports and binary GTA indicators with 5-year intervals between cross sections - employed fixed country-pair effects under the assumption that the inclination toward selecting into a (goods) trade agreement was relatively time-invariant. In this case, fixed country-pair effects would control for the selection bias (see Wooldridge 1995, for a formal treatment of this assumption). Tables 5 and 6 summarize the relevant coefficient estimates on two versions of the discrete treatment variable of interest and all the controls included in Table 4. One version of the treatment variable is a count variable as in Tables 1 and 2; which was the dependent variable underlying the results in Table 4 . This variable is

8 Similar to linear regression models, matching based on the propensity score requires that all relevant variables are included in the model (so that the estimates - with matching, including the propensity score - are consistent). Notice that Assumption Al is not testable.

9 For observations to be comparable, country-pairs with a specific treatment and control level of the scope of preferentialism in a given year $t$ should have overlapping probabilities of having the same scope as the treated. Otherwise, the units would be too dissimilar to infer causal treatment effects from.

10 Suppose units of observation with specific treatment and control levels of the scope of preferentialism had similar, overlapping probabilities of exhibiting the level of treatment of the treated but the respective determinants $\mathbf{X}_{s, \tilde{s}}$ of those treatment probabilities would be very dissimilar for units with treatment $s$ versus $\tilde{s}$. Then, similarity in propensity scores would be an artifact and not a compact measure of similarity in the underlying $\mathbf{X}_{s, \tilde{s}}$, which they are supposed to be. 
Table 5: Average treatment effects in linear fixed effects models.

\begin{tabular}{|c|c|c|c|c|}
\hline & $\begin{array}{l}\text { Outcome: } \\
\text { intensive } \\
\text { country } \\
\text { margin }\end{array}$ & $\begin{array}{l}\text { Outcome: } \\
\text { intensive } \\
\text { country } \\
\text { margin }\end{array}$ & $\begin{array}{l}\text { Outcome: } \\
\text { extensive } \\
\text { country } \\
\text { margin }\end{array}$ & $\begin{array}{l}\text { Outcome: } \\
\text { extensive } \\
\text { country } \\
\text { margin }\end{array}$ \\
\hline Scope of preferentialism $i j t$ & $\begin{array}{l}0.303^{\star \star \star} \\
(0.006)\end{array}$ & & $\begin{array}{l}-0.070^{\star \star \star} \\
(0.001)\end{array}$ & \\
\hline Treatment scope $l_{i j t}$ & & $\begin{array}{l}0.238^{\star \star \star} \\
(0.010)\end{array}$ & & $\begin{array}{l}-0.049^{\star \star \star} \\
(0.002)\end{array}$ \\
\hline Treatment scope $2_{i j t}$ & & $\begin{array}{l}0.647^{\star \star *} \\
(0.014)\end{array}$ & & $\begin{array}{l}-0.152^{\star \star \star} \\
(0.003)\end{array}$ \\
\hline Treatment scope $3_{i j t}$ & & $\begin{array}{l}0.962^{\star \star \star} \\
(0.020)\end{array}$ & & $\begin{array}{l}-0.246^{\star \star \star} \\
(0.004)\end{array}$ \\
\hline Treatment scope $4_{i j t}$ & & $\begin{array}{l}1.186^{\star \star *} \\
(0.042)\end{array}$ & & $\begin{array}{l}-0.279^{\star \star \star} \\
(0.007)\end{array}$ \\
\hline SumGDP $i j t$ & $\begin{array}{l}2.210^{\star \star \star} \\
(0.021)\end{array}$ & $\begin{array}{l}2.212^{\star \star \star} \\
(0.021)\end{array}$ & $\begin{array}{l}0.200^{\star \star \star} \\
(0.003)\end{array}$ & $\begin{array}{l}0.200^{\star \star \star} \\
(0.003)\end{array}$ \\
\hline $\operatorname{SimGDP} i j t$ & $\begin{array}{l}0.593^{* * *} \\
(0.015)\end{array}$ & $\begin{array}{l}0.594^{\star \star \star} \\
(0.015)\end{array}$ & $\begin{array}{l}0.047^{\star \star *} \\
(0.002)\end{array}$ & $\begin{array}{l}0.047^{\star \star \star} \\
(0.002)\end{array}$ \\
\hline SumPOP $_{i j t}$ & $\begin{array}{l}-0.201^{\star \star \star} \\
(0.018)\end{array}$ & $\begin{array}{c}-0.198^{\star \star \star} \\
(0.018)\end{array}$ & $\begin{array}{l}0.024^{\star \star \star} \\
(0.003)\end{array}$ & $\begin{array}{l}0.023^{\star \star \star} \\
(0.003)\end{array}$ \\
\hline SimPOP $_{i j t}$ & $\begin{array}{l}0.596^{\star \star \star} \\
(0.021)\end{array}$ & $\begin{array}{l}0.596^{\star * *} \\
(0.021)\end{array}$ & $\begin{array}{l}0.060^{\star \star \star} \\
(0.004)\end{array}$ & $\begin{array}{l}0.060^{\star * \star} \\
(0.004)\end{array}$ \\
\hline $\mathrm{DKL}_{i j t}$ & $\begin{array}{l}-0.063^{\star \star \star} \\
(0.020)\end{array}$ & $\begin{array}{l}-0.063^{\star \star \star} \\
(0.020)\end{array}$ & $\begin{array}{l}-0.014^{\star \star \star} \\
(0.003)\end{array}$ & $\begin{array}{l}-0.014^{\star \star \star} \\
(0.003)\end{array}$ \\
\hline $\mathrm{DKL}_{i j t}^{2}$ & $\begin{array}{l}-0.102^{\star * *} \\
(0.006)\end{array}$ & $\begin{array}{l}-0.102^{\star * *} \\
(0.006)\end{array}$ & $\begin{array}{l}0.003^{* * *} \\
(0.001)\end{array}$ & $\begin{array}{l}0.004^{\star \star *} \\
(0.001)\end{array}$ \\
\hline Remote $_{i j}$ & $\begin{array}{l}2.643^{\star \star \star} \\
(0.158)\end{array}$ & $\begin{array}{l}2.717^{\star \star \star} \\
(0.159)\end{array}$ & $\begin{array}{l}0.626^{\star \star \star} \\
(0.028)\end{array}$ & $\begin{array}{l}0.604^{\star \star \star} \\
(0.028)\end{array}$ \\
\hline DRowKL $_{i j t}$ & $\begin{array}{l}-0.130^{\star \star \star} \\
(0.024)\end{array}$ & $\begin{array}{l}-0.124^{\star \star \star} \\
(0.024)\end{array}$ & $\begin{array}{l}-0.063^{\star \star \star} \\
(0.004)\end{array}$ & $\begin{array}{l}-0.065^{\star \star \star} \\
(0.004)\end{array}$ \\
\hline WTO Member ${ }_{i j t}$ (one) & $\begin{array}{l}-0.169^{\star \star \star} \\
(0.018)\end{array}$ & $\begin{array}{c}-0.166^{\star \star \star} \\
(0.018)\end{array}$ & $\begin{array}{l}0.075^{\star \star \star} \\
(0.003)\end{array}$ & $\begin{array}{c}0.074 \\
(0.003)\end{array}$ \\
\hline WTO Member ${ }_{i j t}$ (both) & $\begin{array}{c}-0.133^{\star * \star} \\
(0.020)\end{array}$ & $\begin{array}{l}-0.129^{\star * *} \\
(0.020)\end{array}$ & $\begin{array}{l}0.145^{\star \star \star} \\
(0.003)\end{array}$ & $\begin{array}{c}0.145 \\
(0.003)\end{array}$ \\
\hline DiffRegDur $_{i j t}$ & $\begin{array}{l}-0.003^{\star * *} \\
(0.000)\end{array}$ & $\begin{array}{l}-0.003^{\star \star *} \\
(0.000)\end{array}$ & $\begin{array}{c}-0.001^{\star \star *} \\
(.000)\end{array}$ & $\begin{array}{c}-0.001 \\
(0.000)\end{array}$ \\
\hline DiffPolFreed $_{i j t}$ & $\begin{array}{c}-0.011^{\star \star \star} \\
(0.001)\end{array}$ & $\begin{array}{c}-0.011^{\star \star \star} \\
(0.001)\end{array}$ & $\begin{array}{l}.001^{\star \star \star} \\
(.000)\end{array}$ & $\begin{array}{c}0.001 \\
(0.000)\end{array}$ \\
\hline Observations & 337,150 & 337,150 & 549,782 & 549,782 \\
\hline Country-pair effects & Yes & Yes & Yes & Yes \\
\hline Time effects & Yes & Yes & Yes & Yes \\
\hline Pairs & 15,993 & 15,993 & 17,606 & 17,606 \\
\hline Adj. $R^{2}$ & 0.818 & 0.8181 & 0.5476 & 0.5478 \\
\hline
\end{tabular}

Notes: OLS estimates. ${ }^{* \star \star},{ }^{\star \star}$, and ${ }^{*}$ indicate that coefficients are significantly different from zero at $1 \%, 5 \%$, and $10 \%$, respectively. Treatment scope $1(2-4)$ is (are) dummy variable(s) indicating the respective scope of preferential agreements of a country-pair. 
Table 6: Average treatment effects on goods export margins in linear fixed effects models (additionally including continent-time effects).

\begin{tabular}{|c|c|c|c|c|}
\hline & $\begin{array}{l}\text { Outcome: } \\
\text { intensive } \\
\text { country } \\
\text { margin }\end{array}$ & $\begin{array}{l}\text { Outcome: } \\
\text { intensive } \\
\text { country } \\
\text { margin }\end{array}$ & $\begin{array}{l}\text { Outcome: } \\
\text { extensive } \\
\text { country } \\
\text { margin }\end{array}$ & $\begin{array}{l}\text { Outcome: } \\
\text { extensive } \\
\text { country } \\
\text { margin }\end{array}$ \\
\hline Scope of preferentialism $i j t$ & $\begin{array}{l}0.272^{\star \star \star} \\
(0.006)\end{array}$ & & $\begin{array}{l}-0.069^{\star \star \star} \\
(0.001)\end{array}$ & \\
\hline Treatment scope $l_{i j t}$ & & $\begin{array}{l}0.228^{\star \star \star} \\
(0.010)\end{array}$ & & $\begin{array}{c}-0.047^{\star \star \star} \\
0.002\end{array}$ \\
\hline Treatment scope $2_{i j t}$ & & $\begin{array}{l}0.575^{\star \star \star} \\
(0.014)\end{array}$ & & $\begin{array}{l}-0.149^{\star \star \star *} \\
0.004\end{array}$ \\
\hline Treatment scope $3_{i j t}$ & & $\begin{array}{l}0.835^{\star * \star} \\
(0.020)\end{array}$ & & $\begin{array}{c}-0.247^{\star \star \star} \\
0.007\end{array}$ \\
\hline Treatment scope $4_{i j t}$ & & $\begin{array}{l}1.132^{\star \star \star} \\
(0.042)\end{array}$ & & $\begin{array}{l}-0.272^{\star \star \star} \\
0.017\end{array}$ \\
\hline SumGDP $_{i j t}$ & $\begin{array}{l}2.383^{\star \star \star} \\
0.024\end{array}$ & $\begin{array}{l}2.383^{\star \star \star} \\
0.024\end{array}$ & $\begin{array}{l}0.228^{\star \star \star \star} \\
0.004\end{array}$ & $\begin{array}{l}0.228^{\star \star \star} \\
0.004\end{array}$ \\
\hline $\operatorname{SimGDP}_{i j t}$ & $\begin{array}{l}0.629 \star \star \star \\
0.015\end{array}$ & $\begin{array}{l}0.630^{\star \star \star} \\
0.015\end{array}$ & $\begin{array}{l}0.054^{\star \star \star} \\
0.002\end{array}$ & $\begin{array}{l}0.054^{\star \star \star} \\
0.002\end{array}$ \\
\hline SumPOP $_{i j t}$ & $\begin{array}{r}-0.002 \\
0.018\end{array}$ & $\begin{array}{r}-0.001 \\
0.018\end{array}$ & $\begin{array}{l}0.025^{\star \star \star} \\
0.003\end{array}$ & $\begin{array}{l}0.025^{\star \star \star} \\
0.003\end{array}$ \\
\hline $\operatorname{SimPOP}_{i j t}$ & $\begin{array}{l}0.506^{\star \star \star} \\
0.023\end{array}$ & $\begin{array}{l}0.505^{\star \star \star} \\
0.023\end{array}$ & $\begin{array}{l}0.086^{\star \star \star} \\
0.004\end{array}$ & $\begin{array}{l}0.087^{\star \star \star} \\
0.004\end{array}$ \\
\hline $\mathrm{DKL}_{i j t}$ & $\begin{array}{l}-0.062^{\star \star \star} \\
0.019\end{array}$ & $\begin{array}{l}-0.062^{\star \star \star} \\
0.019\end{array}$ & $\begin{array}{l}-0.010^{\star \star \star} \\
0.003\end{array}$ & $\begin{array}{l}-0.010^{\star \star \star *} \\
0.003\end{array}$ \\
\hline $\mathrm{DKL}_{i j t}^{2}$ & $\begin{array}{l}-0.114^{\star \star \star *} \\
0.006\end{array}$ & $\begin{array}{l}-0.114^{\star \star \star} \\
0.006\end{array}$ & $\begin{array}{l}0.001 \\
0.001\end{array}$ & $\begin{array}{l}0.001 \\
0.001\end{array}$ \\
\hline Remote $_{i j}$ & $\begin{array}{l}4.774^{\star \star \star} \\
0.304\end{array}$ & $\begin{array}{l}4.785^{\star \star \star} \\
0.304\end{array}$ & $\begin{array}{l}0.658^{\star \star \star} \\
0.048\end{array}$ & $\begin{array}{l}0.656^{\star \star \star} \\
0.048\end{array}$ \\
\hline DRowKL $_{i j t}$ & $\begin{array}{l}0.066^{\star \star *} \\
0.024\end{array}$ & $\begin{array}{l}0.070^{\star \star \star} \\
0.024\end{array}$ & $\begin{array}{l}-0.060^{\star * \star} \\
0.004\end{array}$ & $\begin{array}{l}-0.061^{\star \star \star} \\
0.004\end{array}$ \\
\hline WTO Member $_{i j t}$ (one) & $\begin{array}{c}-0.101^{\star \star \star} \\
0.018\end{array}$ & $\begin{array}{l}-0.100^{\star \star \star} \\
0.018\end{array}$ & $\begin{array}{l}0.077^{\star \star \star} \\
0.003\end{array}$ & $\begin{array}{l}0.077^{\star \star \star} \\
0.002\end{array}$ \\
\hline WTO Member $_{i j t}$ (both) & $\begin{array}{l}-0.053^{\star \star \star} \\
0.020\end{array}$ & $\begin{array}{c}-0.052^{\star \star \star} \\
0.020\end{array}$ & $\begin{array}{l}0.146^{\star \star \star} \\
0.003\end{array}$ & $\begin{array}{l}0.146^{\star \star \star} \\
0.003\end{array}$ \\
\hline DiffRegDur $_{i j t}$ & $\begin{array}{l}-0.003^{\star \star \star} \\
0.000\end{array}$ & $\begin{array}{l}-0.003^{\star \star \star} \\
0.000\end{array}$ & $\begin{array}{l}-0.001^{\star \star \star} \\
0.000\end{array}$ & $\begin{array}{l}-0.001^{\star \star \star} \\
0.000\end{array}$ \\
\hline DiffPolFreed $_{i j t}$ & $\begin{array}{c}-0.006^{\star \star \star} \\
0.001\end{array}$ & $\begin{array}{c}-0.006^{\star * *} \\
0.001\end{array}$ & $\begin{array}{l}0.001^{\star * \star} \\
0.000\end{array}$ & $\begin{array}{l}0.001^{\star \star *} \\
0.000\end{array}$ \\
\hline Observations & 337,150 & 337,150 & 549,782 & 549,782 \\
\hline Country-pair effects & Yes & Yes & Yes & Yes \\
\hline Continent-time effects & Yes & Yes & Yes & Yes \\
\hline Pairs & 15,993 & 15,993 & 17,606 & 17,606 \\
\hline Adj. $R^{2}$ & 0.822 & 0.822 & 0.550 & 0.550 \\
\hline
\end{tabular}

Notes: OLS estimates. ${ }^{* \star *},{ }^{\star *}$, and ${ }^{*}$ indicate that coefficients are significantly different from zero at $1 \%, 5 \%$, and $10 \%$, respectively. Treatment scope $1(2-4)$ is (are) dummy variable(s) indicating the respective scope of preferential agreements of a country-pair. 
dubbed Scope of preferentialism ${ }_{i j t}$ in Tables 5 and 6. In a linear fixed country-pair effects model, such a specification forces the impact of scope of preferentialism to be linear. Therefore, alternatively, we employ four individual binary variables simultaneously (with a zero scope being the reference category) in order to allow for a nonlinear impact of a bigger scope of preferentialism as the scope changes gradually from one to four. We employ two versions of these two specifications, where one employs fixed common time effects (in Table 5) and another one allows the time effects to be continent specific (in Table 6). Since there are always two countries in a pair, there are two continent-specific year effects involved in the latter case. ${ }^{11}$ With two export margins (intensive and extensive), two specifications of functional form of the average treatment effect of the scope of preferentialism, and two specifications of year fixed effects (common or continent-specific), there are eight models altogether.

The results in Tables 5 and 6 support the following conclusions. First, the results based on the scope measured by a count variable suggest a positive, linear relationship between scope and the intensive margin of exports, but not the extensive margin of exports. This holds true, no matter of whether time effects are specified as common or specific to continents. A parameter of 0.272 in the models for log bilateral exports means that trade is growing by $100 \cdot \exp (0.272)-100 \%$ if the scope of preferentialism grows by one mode. A parameter of -0.07 in the linear probability models for positive exports means that the probability of positive exports declines by seven percentage points if the scope of preferentialism grows by one mode. Second, the results suggest that the semi-elasticity of the scope of preferentialism for the intensive margin of exports or the percentage point effect on the probability does not progress linearly as the scope increases from zero up to four.

Two drawbacks of these estimates based on a linear model are that they invoke relatively strong functional form assumptions regarding the impact of treatment on outcome and that they do not impose strict support conditions. An important consequence of these drawbacks is that the observations with different treatment levels still differ in a nonlinear fashion with regard to the included observables and are, in fact, not comparable. Moreover, the selection problem might be time-variant (as are the observables determining selection) such that the parameter estimates might be inconsistent. However, given the restrictions of the fixed effect model, it has two advantages: the average treatment effects of the treated are identical to the average treatment effects of the untreated which facilitates the interpretation of the results; the estimates are based on a full

11 In principal, one could allow even for country-specific rather than continent-specific year effects. However, with the data at hand, the model's objective function is difficult to optimize for parameter values in that case. Therefore, we resort to the more parsimonious specification. 
support of the data so that a quantitative comparison between any combination of treatment levels is straightforward.

While Baier and Bergstrand (2007) focus on the intensive margin of goods trade, we would like to emphasize at this point that using panel data with fixed country-pair effects and a binary indicator variable to estimate effects at the extensive country margin of trade is done here for completeness. It turns out that the Baier-Bergstrand approach in context of the extensive margin is not trustworthy with long panels of country-pairs for the following reason. The dependent variable in this case is a binary indicator. This indicator is zero for $39 \%$ of the observations between 1960 and 2005, and it is unity more likely in recent years (for $77.6 \%$ of the country-pairs in 2005 versus $42.8 \%$ in 1960). Clearly, the fixed country-pair effects estimator identifies the coefficient only from those country-pairs that (i) switched export status and (ii) switched treaty status between 1960 and 2005. These are only 10.8\% of the observations. And for those observations, the estimator does not guarantee to obtain predictions in the interval $[0,1]$, so that estimated probabilities may be biased. In contrast, the matching approach entertains variation from all 16,050 country-pairs in 2005, so that the estimates are less comparable between the matching estimator and the fixed effects estimator for the extensive margin than they are for the intensive margin, where both estimators are based on an identical number of observations on outcome.

In view of the aforementioned limitations of linear modeling, it seems desirable to move on to nonparametric identification along the lines of Section 2. Before summarizing the findings, let us emphasize that the less restrictive functional form assumptions and cleaner identification in comparison to fixed effects modeling renders global comparisons of effects more difficult, since the support which is common to a comparison of observations with one or the other scope of preferentialism differs between different treatment and control states. One consequence of the latter is also that average treatment effects of the treated may differ from average treatment effects of the untreated (and of average treatment effects as a weighted average of the two).

Tables 7 and 8 summarize the estimates of $A T T_{s, \tilde{s}}^{\mathcal{I}}$ and $A T T_{s, \tilde{s}}^{\mathcal{E}}$ and their standard errors. In both tables, we focus on data of 2005 to ensure that treated observations are matched onto ones of the same year. The corresponding results should be interpreted as ones where the change in propensity scores since the beginning (1960) until the end of the sample period (2005) is the same between treated and control units, and the estimated effects are associated with changes in treatment. ${ }^{12}$

\footnotetext{
12 Suppose that the propensity of having any scope other than 0 is zero in some initial period. Then, the level of propensity of having a given scope greater than 0 in a later period does represent not only the propensity of having that state but also the change in propensity relative to the initial period.
} 
Table 7: ATTs at intensive export margin.

\begin{tabular}{|c|c|c|c|c|c|}
\hline \multirow[t]{2}{*}{ Treatment scope } & \multicolumn{5}{|c|}{ Control scope of preferentialism } \\
\hline & 0 & 1 & 2 & 3 & 4 \\
\hline 0 & . & $\begin{array}{l}-1.012^{\star \star \star} \\
(0.040)\end{array}$ & $\begin{array}{l}-1.046^{\star \star \star} \\
(0.046)\end{array}$ & $\begin{array}{l}-2.829^{\star \star \star} \\
(0.061)\end{array}$ & $\begin{array}{l}-3.176^{\star * \star} \\
(0.093)\end{array}$ \\
\hline 1 & $\begin{array}{l}1.169^{* * *} \\
(0.068)\end{array}$ & . & $\begin{array}{l}-0.283^{* * *} \\
(0.065)\end{array}$ & $\begin{array}{l}-1.278^{\star * \star} \\
(0.071)\end{array}$ & $\begin{array}{l}-1.697^{\star \star \star} \\
(0.082)\end{array}$ \\
\hline 2 & $\begin{array}{l}1.714^{\star \star \star} \\
(0.103)\end{array}$ & $\begin{array}{l}0.467^{\star \star \star} \\
(0.092)\end{array}$ & . & $\begin{array}{l}-0.592^{\star \star \star} \\
(0.073)\end{array}$ & $\begin{array}{l}-0.947^{\star \star \star} \\
(0.077)\end{array}$ \\
\hline 3 & $\begin{array}{l}2.336^{\star \star \star} \\
(0.165)\end{array}$ & $\begin{array}{l}1.128^{\star \star \star} \\
(0.144)\end{array}$ & $\begin{array}{l}0.547^{\star \star \star} \\
(0.116)\end{array}$ & . & $\begin{array}{l}-0.395^{\star \star \star} \\
(0.093)\end{array}$ \\
\hline 4 & $\begin{array}{l}2.724^{\star \star *} \\
(0.349)\end{array}$ & $\begin{array}{l}1.439 * \star \star \\
(0.298)\end{array}$ & $\begin{array}{l}1.011^{\star \star *} \\
(0.224)\end{array}$ & $\begin{array}{l}0.424^{\star \star} \\
(0.167)\end{array}$ & $\cdot$ \\
\hline
\end{tabular}

Notes: ATTs and standard errors (in parentheses) on the $\log$ of bilateral goods exports (intensive margin) in 2005. ${ }^{\star \star \star},{ }^{* \star}$, and * indicate that coefficients are significantly different from zero at $1 \%$, $5 \%$, and $10 \%$, respectively.

Table 8: ATTs at extensive export margin.

\begin{tabular}{|c|c|c|c|c|c|}
\hline \multirow[t]{2}{*}{ Treatment scope } & \multicolumn{5}{|c|}{ Control scope of preferentialism } \\
\hline & 0 & 1 & 2 & 3 & 4 \\
\hline 0 & . & $\begin{array}{l}-0.113^{\star \star \star} \\
(0.005)\end{array}$ & $\begin{array}{l}-0.114^{\star \star *} \\
(0.005)\end{array}$ & $\begin{array}{c}-0.079^{\star * \star} \\
(0.006)\end{array}$ & $\begin{array}{l}-0.062^{\star \star \star} \\
(0.008)\end{array}$ \\
\hline 1 & $\begin{array}{l}0.062^{\star \star \star} \\
(0.007)\end{array}$ & . & $\begin{array}{l}-0.016^{\star \star *} \\
(0.006)\end{array}$ & $\begin{array}{c}-0.011^{\star} \\
(0.006)\end{array}$ & $\begin{array}{c}-0.014^{\star \star} \\
(0.006)\end{array}$ \\
\hline 2 & $\begin{array}{l}0.058^{\star \star \star} \\
(0.009)\end{array}$ & $\begin{array}{c}0.015^{\star \star} \\
(0.007)\end{array}$ & . & $\begin{array}{l}0.006^{\star \star} \\
(0.002)\end{array}$ & . \\
\hline 3 & $\begin{array}{l}0.050^{\star \star *} \\
(0.013)\end{array}$ & $\begin{array}{c}0.013 \\
(0.008)\end{array}$ & $\begin{array}{c}-0.003 \\
(0.003)\end{array}$ & . & $\begin{array}{c}-0.002 \\
(0.003)\end{array}$ \\
\hline 4 & $\begin{array}{c}0.075^{\star} \\
(0.039)\end{array}$ & $\begin{array}{c}0.013 \\
(0.022)\end{array}$ & $\begin{array}{c}0.000 \\
(0.008)\end{array}$ & $\begin{array}{c}0.002 \\
(0.005)\end{array}$ & . \\
\hline
\end{tabular}

Notes: ATTs and standard errors (in parentheses) on the probability of positive bilateral goods exports (extensive margin) in 2005. ${ }^{\star * \star}$, $*$, and * indicate that coefficients are significantly different from zero at $1 \%, 5 \%$, and $10 \%$, respectively.

In this sense, we may refer to these estimates as long-run effects. The results for the intensive margin indicate that a larger extent of preferentialism is generally associated with positive effects on goods trade. This can easily be seen by comparing the respective ATTs in Table 7. First, the elements above the principal diagonal in Table 7 indicate that there is less trade on average with a narrower scope of preferentialism for treated relative to control units. The elements below the 


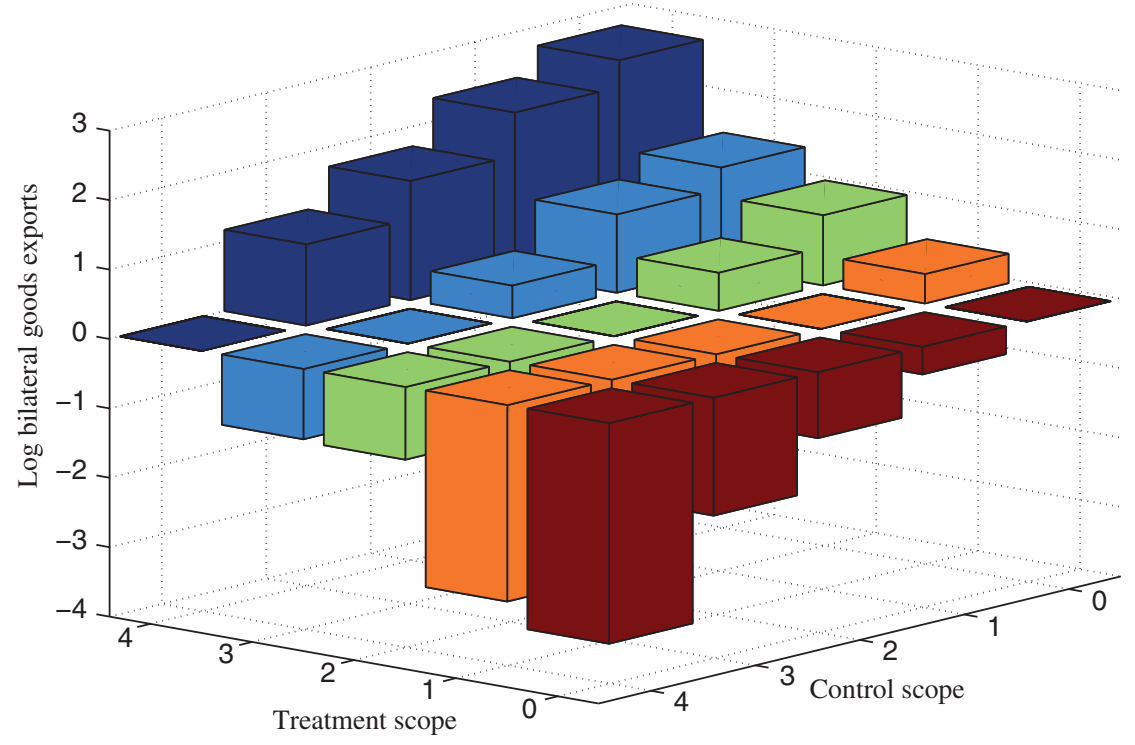

Figure 4: ATTs at intensive export margin.

Notes: The figure depicts the matrix of estimated ATTs presented in Table 7.

principal diagonal in Table 7 indicate that the opposite is true on average with a broader scope of preferentialism for treated relative to control units. The matrices in Tables 7 and 8 are not symmetric which suggests that the ATTs differ from average treatment effects of the untreated due to differences in the support. The latter point is highlighted in Figure 4, which depicts the matrix of estimated ATTs presented in Table 7 in a three-dimensional histogram. In this histogram, the horizontal axes display the treatment scope and the control scope. On the vertical axis, we display the log of bilateral goods exports. The tallest blue bar in the back indicates the effect of covering preferential market access through four modes of PEIAs relative to a situation without any preferential market access. The staircase on the righthand side in the back indicates, for example, how goods exports are affected when first implementing one PEIA (orange), then adding another one (green), a third one (light blue), and a fourth one (dark blue).

Second, for a given treatment scope (row) in the upper bloc of Table 7, the estimated ATTs tend to increase in absolute value as we move away from the principal diagonal. Thus, the effects of a broader scope of preferentialism on the level of positive trade gradually increase with a broader scope of the treated relative to the control pairs. As said before, this has to be interpreted with some care since the effect of increasing the scope from, say, 0 to 1 is based on a different support for control units with a treatment of 0 in the data than the 
effect of increasing the scope from, say, 0 to 2, etc. In principal, this feature could be removed by enforcing the support for the control treatment to be the same across all comparisons, but this comes at the cost of a potentially high efficiency loss.

Broadening the scope of preferentialism raises both margins of trade. However, it seems to matter in particular at the intensive margin of trade (in Table 7), but less so at the extensive margin of trade (in Table 8). For the latter statement, the issue of support is particularly important since all observations with zero bilateral exports are excluded from the support underlying the ATTs at the intensive margin in Table 7.

With respect to the extensive margin, results broadly confirm the pattern found for the intensive margin, in contrast to the linear probability models in Tables 5 and 6. Apart from some insignificant ATTs estimated for treatment scopes 3 and 4 (for control scopes 1-3, respectively), treatments with a higher degree of integration increase the probability of country-pairs trading goods. Negative ATTs are found for combinations where the control scope exceeds the treatment scope, except for $A T T_{2, \tilde{3}}^{\mathcal{E}}=0.006$, which is, however, a relatively small effect. On average, focusing on a control scope of 0 , a higher treatment scope of any kind and of any extent leads to an $\sim 6 \%$ higher probability of country-pairs to exchange goods. ${ }^{13}$

We assessed the sensitivity of these findings in three substantial ways. First, we utilized an alternative classification of investment agreements to the benchmark results as in the second column of Table 4 and based matching on the associated propensity scores. The results turned out to be qualitatively insensitive to this change. Second, we estimated $A T T_{s, \tilde{s}}^{\mathcal{I}}$ and $A T T_{s, \tilde{s}}^{\mathcal{E}}$ based on the propensity scores from a dynamic model as in the third column of Table 4. Again, the qualitative insights from Tables 7 and 8 were unchanged when using this more complicated approach relative to the more parsimonious one described above. Third, we estimated $A T T_{s, \tilde{\mathcal{S}}}^{\mathcal{I}}$ and $A T T_{s, \tilde{s}}^{\mathcal{E}}$ based on a model including the weighted scope of preferentialism in other countries than $i$ and $j$ in the previous year, as in Table 4. In all conducted sensitivity checks, the

13 Notice that, following Lechner (2001), one may compute average treatment effects - say, $A T E_{s . \tilde{s}}^{\mathcal{I}}$ and $A T E_{s . \tilde{s}}^{\mathcal{E}}$ - based on the results reported in Tables 7 and 8, which can be compared to the scope-specific average treatment effects in Tables 5 and 6. In Table 9, we do so for the intensive margin of trade $A T E_{s, \tilde{s}}^{\mathcal{I}}$. Besides these scope-dyad-specific ATEs, we report scopespecific average treatment effects $A T E_{s}^{\mathcal{I}}$ in the same table. The latter can be compared with the results on the scope-specific average treatment effects on the intensive margin of exports in Tables 5 and 6 . The findings suggest that the average treatment effect of broadening the scope depends on the initial state of liberalization, which is not accounted for in the estimates in Tables 5 and 6. 
Table 9: Scope-dyad-specific $\left(A T E_{s, \tilde{s}}^{\mathcal{I}}\right)$ and scope-specific $\left(A T E_{s}^{\mathcal{I}}\right)$ ATEs at intensive export margin based on findings in table 7 .

\begin{tabular}{|c|c|c|c|c|c|}
\hline \multirow[t]{2}{*}{ Treatment scope } & \multicolumn{4}{|c|}{ Control scope of preferentialism } & \multirow[t]{2}{*}{$\operatorname{ATE}_{s}^{\mathcal{I}}$} \\
\hline & 0 & 1 & 2 & 3 & \\
\hline \multirow[t]{2}{*}{0} & . & . & . & . & . \\
\hline & . & . & . & . & . \\
\hline \multirow[t]{2}{*}{1} & $1.051^{\star \star \star}$ & . & . & . & $1.051^{\star \star *}$ \\
\hline & $(0.048)$ & . & . & . & $(0.048)$ \\
\hline \multirow[t]{2}{*}{2} & $1.129^{\star \star \star}$ & $0.338^{\star \star \star}$ & . & . & $0.895^{\star \star *}$ \\
\hline & $(0.056)$ & $(0.074)$ & . & . & $(0.062)$ \\
\hline \multirow[t]{2}{*}{3} & $2.772^{\star \star \star}$ & $1.258^{\star \star \star}$ & $0.579 * \star \star$ & . & $1.781^{\star \star \star}$ \\
\hline & $(0.081)$ & $(0.085)$ & $(0.087)$ & . & $(0.083)$ \\
\hline \multirow[t]{2}{*}{4} & $3.144^{\star \star \star}$ & $0.921^{\star \star \star}$ & $0.954^{\star \star \star}$ & $0.402^{\star \star \star}$ & $1.567^{\star \star \star}$ \\
\hline & $(0.130)$ & $(0.101)$ & $(0.105)$ & $(0.116)$ & $(0.113)$ \\
\hline
\end{tabular}

Notes: Average treatment effects (ATES) and standard errors (in parentheses) on the probability of positive bilateral goods exports (extensive margin) in 2005. ${ }^{\star \star \star},{ }^{\star *}$, and * indicate that coefficients are significantly different from zero at $1 \%, 5 \%$, and $10 \%$, respectively.

qualitative insights from the analysis in Tables 7 and 8 were unchanged. The reason for the qualitative insensitivity of the results to those changes is that the estimated propensity scores are relatively similar for the year 2005 across the different experiments. Hence, the treatment and control groups are similar and so are the estimated average treatment effects on the treated.

\section{Conclusions}

There is a long-standing tradition in empirical work on the effects of preferential economic policy effects on economic outcomes in adopting a unimodal approach: GTAs affect goods trade, STAs affect services trade, and foreign investment provisions affect foreign direct investment. In reality, especially large firms pursue an array of interdependent activities which cover goods and services trade as well as foreign direct investments. This makes cross-issue effects likely, leading to responses of goods trade not only to preferentialism in the goods domain but also to preferentialism in the services and investment domains.

This paper provides evidence of such effects by focusing on the scope of preferentialism in four domains: goods trade, services trade, investment by way of DTTs. It documents generally positive effects from broadening the scope of 
preferentialism by granting preferential market access beyond zero, in one, two, etc., dimensions.

Data show that countries often start their path of preferentialism by granting market access either for investment (through investment or tax provisions) or for goods trade, and only some of the countries continue to integrate beyond the scope of one. The findings in this article suggest that the average country-pair gains from broadening the scope of preferentialism beyond one-dimensional forms.

Acknowledgments: We would like to thank the editor and three anonymous reviewers for numerous helpful comments on an earlier version of the manuscript. Egger acknowledges funding from GA ČR through grant number P402/12/ 0982.

\section{References}

Arcand, Jean-Louis, Marcelo Olarreaga, and Laura Zoratto. 2010. "Weak Governments and Trade Agreements," unpublished manuscript, University of Geneva.

Baier, Scott L., and Jeffrey H. Bergstrand. 2004. "Economic Determinants of Free Trade Agreements." Journal of International Economics 64(1):29-63.

Baier, Scott L., and Jeffrey H. Bergstrand. 2007. "Do Free Trade Agreements Actually Increase Members' International Trade?” Journal of International Economics 71(1):72-95.

Baier, Scott L., and Jeffrey H. Bergstrand. 2009. "Estimating the Effects of Free Trade Agreements on International Trade Flows using Matching Econometrics." Journal of International Economics 77(1):63-76.

Baldwin, Richard E. 1995. “A Domino Theory of Regionalism.” In Expanding Membership in the European Union, edited by R. E. Baldwin, P. Haaparanta, and L. Kiander, 25-53. Cambridge: Cambridge University Press.

Baldwin, Richard E. 1997. "The Causes of Regionalism." The World Economy 20(7):865-88.

Baldwin, Richard E. 2011. 21st Century Regionalism: Filling the Gap Between 21st Century Trade and 20th Century Trade Rules, CEPR Policy Insight No. 56, Centre for Economic Policy Research, London.

Bergstrand, Jeffrey H., and Peter H. Egger. 2011. "The Determinants of BITs," unpublished manuscript.

Bergstrand, Jeffrey H., Peter H. Egger, and Mario Larch. 2010. "The Timing of Preferential Trade Agreement Membership," unpublished manuscript.

Blonigen, Bruce, and Ronald B. Davies. 2004. "The Effects of Bilateral Tax Treaties on U.S. FDI Activity." International Tax and Public Finance 11(5):601-22.

Bond, Eric W., and Constantinos Syropoulos. 1996. "The Size of Trading Blocs. Market Power and World Welfare Effects." Journal of International Economics 40(3-4):411-37.

Chamberlain, Gary. 1982. "Multivariate Regression Models for Panel Data." Journal of Econometrics 18(1):5-46. 
Davies, Ronald B. 2003. "The OECD Model Tax Treaty: Tax Competition and Two-Way Capital Flows." International Economic Review 44(2):725-53.

Davies, Ronald B. 2004. "Tax Treaties and Foreign Direct Investment: Potential versus Performance." International Tax and Public Finance 11(6):775-802.

Davies, Ronald B., Hartmut Egger, and Peter H. Egger. 2010. "Profit Taxation and the Mode of Foreign Market Entry." Canadian Journal of Economics 43(2):704-27.

Davies, Ronald B., Pehr-Johan Norback, and Ayca Tekin-Koru. 2009. "The Effect of Tax Treaties on Multinational Firms: New Evidence from Microdata." The World Economy 32(1):77-110.

Dorn, Sabrina, and Peter H. Egger. 2011. "On the Distribution of Exchange Rate Regime Treatment Effects on International Trade," CEPR Discussion Paper no. 8654.

Egger, Peter H., and Mario Larch. 2008. "Interdependent Preferential Trade Agreement Memberships: An Empirical Analysis.” Journal of International Economics 76(2):384-99.

Egger, Peter H., Mario Larch, and Michael Pfaffermayr. 2004. "Multilateral Trade and Investment Liberalization: Effects on Welfare and GDP Per Capita Convergence." Economics Letters 84(1):133-40.

Egger, Peter H., Mario Larch, and Michael Pfaffermayr. 2007a. On the Welfare Effects of Trade and Investment Liberalization." European Economic Review 51(3):669-94.

Egger, Peter H., Mario Larch, and Michael Pfaffermayr. 2007b. Bilateral versus Multilateral Trade and Investment Liberalization." The World Economy 30(4):567-96.

Egger, Peter H., Mario Larch, Michael Pfaffermayr, and Hannes Winner. 2006. "The Impact of Endogenous Tax Treaties on Foreign Direct Investment: Theory and Empirical Evidence." Canadian Journal of Economics 39(3):901-31.

Egger, Peter H., Mario Larch, and Kevin Staub. 2012. "Trade Preferences and Bilateral Trade in Goods and Services: A Structural Approach,” CEPR Discussion Paper no. 9051.

Egger, Peter H., Mario Larch, Kevin Staub, and Rainer Winkelmann. 2011. "The Trade Effects of Endogenous Preferential Trade Agreements.” American Economic Journal: Economic Policy 3(3):113-43.

Egger, Peter H., and Rainer Lanz. 2008. "The Determinants of GATS Commitment Coverage.” The World Economy 31(12):1666-94.

Egger, Peter H., and Valeria Merlo. 2012. "BITs Bite: An Anatomy of the Impact of Bilateral Investment Treaties on Multinational Firms." Scandinavian Journal of Economics 114(4):1240-66.

Egger, Peter H., and Douglas R. Nelson. 2010. "How Bad Is Antidumping? Evidence from Panel Data." Review of Economics and Statistics 93(4):1374-90.

Egger, Peter H., and Georg Wamser. 2013. "Multiple Faces of Preferential Market Access: Their Causes and Consequences.” Economic Policy 28(73):145-87.

Ekholm, Karolina, Rikard Forslid, and James R. Markusen. 2007. "Export-Platform Foreign Direct Investment." Journal of the European Economic Association 5(4):776-95.

Francois, Joseph, and Bernard Hoekman. 2010. "Services Trade and Policy." Journal of Economic Literature 48(3):642-92.

Frankel, Jeffrey A., Ernesto Stein, and Shang-JinWei. 1995. "Trading Blocs and the Americas: The Natural, the Unnatural, and the Super-Natural." Journal of Development Economics 47(1):61-95.

Freund, Caroline. 2000. "Different Paths to Free Trade: The Gains from Regionalism." Quarterly Journal of Economics 115(4):1317-41.

Helpman, Elhanan E., Marc J. Melitz, and Stephen R. Yeaple. 2004. "Export versus FDI with Heterogenous Firms.” American Economic Review 94(1):300-16. 
Horn, Henrik, Petros C. Mavroidis, and Andre Sapir. 2010. "Beyond the WTO? An Anatomy of EU and US Preferential Trade Agreements.” The World Economy 33(11):1565-88.

Huang, Hui, John Whalley, and Shunming Zhang. 2009. "Exploring Policy Options in Joint Intertemporalspatial Trade Models using an Incomplete Markets Approach." Economic Theory 41(1):131-45.

Karacaovali, Baybars, and Nuno Limao. 2008. "The Clash of Liberalizations: Preferential vs. Multilateral Trade Liberalization in the European Union." Journal of International Economics 74(2):299-372.

Limao, Nuno. 2007. "Are Preferential Trade Agreements with Non-Trade Objectives a Block for Multilateral Liberalization?" Review of Economic Studies 74(3):821-55.

Limao, Nuno, and Patricia Tovar Rodriguez. 2011. "Policy Choice: Theory and Evidence from Commitment via International Trade Agreements." Journal of International Economics 85(2):186-205.

Magee, Christopher S. 2003. "Endogenous Preferential Trade Agreements: An Empirical Analysis.” Contributions to Economic Analysis \& Policy 2:Article 15.

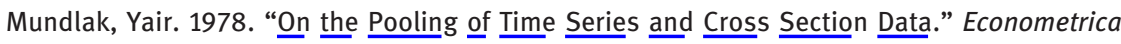
46(1):69-85.

Ornelas, Emanuel. 2005a. Endogenous Free Trade Agreements and the Multilateral Trading System." Journal of International Economics 67(2):471-97.

Ornelas, Emanuel. 2005b. Trade Creating Free Trade Areas and the Undermining of Multilateralism." European Economic Review 49(7):1717-35.

Ornelas, Emanuel. 2005c. Rent Destruction and the Political Viability of Free Trade Agreements." Quarterly Journal of Economics 120(4):1475-506.

Rosenbaum, Paul R., and Donald B. Rubin, 1983. "The Central Role of the Propensity Score in Observational Studies for Causal Effects." Biometrika 70(1):41-55.

Sauvant, Karl P., and Lisa E. Sachs. 2009. The Effect of Treaties on Foreign Direct Investment: Bilateral Investment Treaties, Double Taxation Treaties and Investment Flows. New York: Oxford University Press.

Wooldridge, Jeffrey M. 1995. "Selection Corrections for Panel Data Models Under Conditional Mean Independence Assumptions." Journal of Econometrics 68(1):115-32.

Wooldridge, Jeffrey M. 2002. Econometric Analysis of Cross Section and Panel Data. Cambridge, MA: MIT Press.

Wooldridge, Jeffrey M. 2005. "Simple Solutions to the Initial Conditions Problem in Dynamic, Nonlinear Panel Data Models with Unobserved Heterogeneity." Journal of Applied Econometrics 20(1):39-54. 
